\title{
Immunostimulant Activity of Flavonoid Isolated from The Acetone Extract of Silver Fern (Pityrogramma calomelanos)
}

\author{
Suyatno Sutoyo*, Ismono, dan Mitarlis \\ Department of Chemistry, Faculty of Mathematics and Natural Science Universitas Negeri Surabaya \\ Jl. Ketintang Surabaya, Indonesia \\ suyatno@unesa.ac.id
}

\begin{abstract}
A flavonoid compound namely kaemferol had been separated from the acetone extract of the silver fern (Pityrogramma calomelanos). It was obtained as yellow needles crystal with m.p. of $271-273{ }^{\circ} \mathrm{C}$. Determination of its structure was conducted by the spectroscopic method and by comparison with reported literature data. Based on the carbon clearance method, isolated flavonoid showed immunostimulant activity with phagocytosis index of 1.846 .
\end{abstract}

Keywords-Pityrogramma calomelanos, kaemferol, immunostimulat activity

\section{INTRODUCTION}

The silver fern (Pityrogramma calomelanos) was one of the ferns widely distributed in tropical Asia, especially Indonesia. It was usually found in open region, slope of mountain, near streams, and old wall [1]. People used this fern as the ornamental plant and phytoremediation land polluted arsenic, mercury, zink, and lead [2]. This fern had been used for traditional medicine. An infusion of the whole plant was used to increase male sexual stamina and to treat female haemorrhaging. The leaves were used externally to heal wounds and stop bleeding. An infusion was used to treat pulmonary conditions. It was also used for asthma, cough, cold, pneumonia, tuberculosis, and whooping cough. An aqueous extract was drunk or applied locally to treat venereal disease in Guyana [3].

Many flavonoids in dihydrochalcone type had been separated from the fern species in Pityrogramma genus. For examples, from Pityrogramma triangularis had been separated 2',6',4-trihydroxy-3',5'-dimethyl-4'-methoxy dihydrochalcone [4]. Previous work, we had reported secondary metabolites isolated from the dichloromethane extract of P. calomelanos' aerial part [5]. Many secondary metabolites from plants have properties as immunostimulants. It can increase the work of the components of the immune system [6]. The secondary metabolites that have bioactivity as immunostimulant agents are terpenoids, steroids, alkaloids and polyphenols [7]. In this paper, we reported the isolation of kaemferol from acetone extract of $P$. calomelanos and assay of its immunostimulat activity using carbon clearance method .

\section{MATERIALS AND METHODS}

A. Material

The materials used in this research were the aerial part of silver fern, $n$-hexane, dichloromethane, chloroform, ethyl acetate, acetone, methanol, $\mathrm{FeCl}_{3}, \mathrm{HCl}, \mathrm{Mg}$ ribbon, kieselgel 60 GF-254 (Merck), precoated silica gel $60 \mathrm{~F}$ 254 (Merck), the male mice, tween 80, physiological $\mathrm{NaCl} 0.9 \%$, Na-EDTA, Na-CMC 0.3\%, acetc acid 1\%, Na-Citri, and chinese ink

\section{B. Instrument}

The instruments used in this research were a set of extraction tools with maceration method, Buchner funnel, rotary vacuum evaporator (Heidolp laborata 4001), a set of thin layer chromatography (TLC) and vacuum liquid chromatography (VLC), Fisher John melting point apparatus, UV spectrophotometer (Shimadzu Pharma Spec. UV-1700), IR spectrophotometer (Perkin Elmer USA 89485), mass spectrophotometer (Shimadzu QP-2010S), and other glass tools.

\section{Sample Preparation}

Silver fern was obtained from Kletak forest, Nongkojajar, Pasuruan, East Java. Before the research it was identified by the Indonesian Institute of Sciences of the Purwodadi Botanical Garden, East Java, Indonesia. Furthermore the sample of the aerial part of the silver fern was cleaned, then dried at room temperature. After that it was milled into a fine powder ready to be extracted.

\section{Extraction and Isolation}

The dried powder of The aerial part dried powdered of $P$. calomelanos (5 kg) was exhaustively extracted successively with $n$-hexane ( $6 \mathrm{~L} \times 3)$, ethyl acetate $(6 \mathrm{~L} \times 3)$, and acetone $(6 \mathrm{~L} \times 3)$ at room temperature. The acetone extract were evaporated in vacuo, revealed $76 \mathrm{~g}$ (blackish brown) residue).

A portion of acetone extract $(5.0 \mathrm{~g})$ was chromatographed by VLC and eluted with solvents of increasing polarity (chloroform, chloroform-methanol, methanol) produced 127 
fractions $(15 \mathrm{~mL}$ each). Removal of the solvent under reduced pressure of the combined fractions of 60-100 gave the brown solid $(1,2 \mathrm{~g})$. It was rechromatographed by FC with chloroform-acetone (9:1) as eluen, obtained 60 fractions $(10 \mathrm{~mL}$ each). The fractions $12-30$ were collected, recrystalized in chloroform-methanol yielded a flavonoid 3 , 5, 7, 4'-tetrahydroxy flavone (kaempferol) (1) (30 mg).

\section{E. Immunostimulant activity using carbon clearance method}

Ten male mice were divided into 2 groups, namely negative control group (Na-CMC 0.3\%) and treatment group (given kaemferol isolate from silver ferns with a dose of $4 \mathrm{mg} / \mathrm{kg} \mathrm{BW}$ ). Each group consisted of 5 test animals were given a solution preparation test orally once a day, for 6 consecutive days. On the 7th day the mice from all groups were taken blood through the tail vein, put it in the drop plate which already contained sodium citrate (anticoagulant). Piped blood as much as $25 \mu \mathrm{L}$, lysed with the addition of $4 \mathrm{~mL}$ of $1 \%$ acetic acid, then the absorbance was measured by UV-Vis spectrophotometer at a wavelength of $650 \mathrm{~nm}$. This first blood sample is used as blank (0th minute). Mice from all groups were injected with a carbon suspension of $0.1 \mathrm{~mL} / 10 \mathrm{~g} \mathrm{BW}$ of mice intravenously at the tail. A total of $25 \mu \mathrm{L}$ of mouse blood were taken at $3,6,9,12$, and 15 minutes, after carbon injection, and treated in the same way as blood taken before carbon injection (0th minute). The data obtained were analyzed using linear regression analysis to determine phagocytic constants and phagocytosis index (IF) [8]

\section{RESULTS AND DISCUSSIONS}

Kaempferol (1) was obtained as yellow needles crystal ( $\mathrm{CHCl}_{3}$-acetone), mp. $271-273^{\circ} \mathrm{C}$, which gave positive test (green) with $\mathrm{FeCl}_{3}$ and Shinoda test (Mg-HCl) (orange). It showed one spot on TLC using three eluents system with $\mathrm{Rf}$ of 0.36 (chloroform-acetone $=3: 1$ ), 0.44 (chloroformethyl acetate $=1: 1$ ), and 0.73 (chloroform-methanol $=5$ : 1). $\mathrm{UV}(\mathrm{MeOH}) \lambda_{\max }(\log \varepsilon): 267,367 \mathrm{~nm} ;(\mathrm{MeOH}+$ $\mathrm{NaOH}): 275,322$ (sh), $405 \mathrm{~nm}$; $\left(\mathrm{MeOH}+\mathrm{AlCl}_{3}\right): 270,353$ (sh), $421 \mathrm{~nm}$; (MeOH+AlCl$\left.{ }_{3}+\mathrm{HCl}\right): 269,351(\mathrm{sh}), 421 \mathrm{~nm}$; $(\mathrm{MeOH}+\mathrm{NaOAc}): \quad 276, \quad 343 \quad(\mathrm{sh}), \quad 426 \mathrm{~nm}$; $\left(\mathrm{MeOH}+\mathrm{NaOAc}+\mathrm{H}_{3} \mathrm{BO}_{3}\right): 270,343(\mathrm{sh}), 423 \mathrm{~nm} . \mathrm{IR}(\mathrm{KBr})$ $\bar{v}_{\max }: 3414(\mathrm{OH}), 3036$ (aromatic C-H), 1659 (chelated $\mathrm{C}=\mathrm{O}), 1613,1567,1510$ (aromatic $\mathrm{C}=\mathrm{C}$ ), 1381, 1308, 1249, $1178 \mathrm{~cm}^{-1}$. ${ }^{1} \mathrm{H}-\mathrm{NMR}\left(500 \mathrm{MHz}, \mathrm{CD}_{3} \mathrm{OD}\right) \delta(\mathrm{ppm}): 6.17$ $(1 \mathrm{H}, d, J=1.9 \mathrm{~Hz}, \mathrm{H}-6), 6.38(1 \mathrm{H}, d, J=1,9 \mathrm{~Hz}, \mathrm{H}-8), 6.89$ $\left(2 \mathrm{H}, d, J=9,2 \mathrm{~Hz}, \mathrm{H}-3^{\prime}, 5^{\prime}\right), 8.07(2 \mathrm{H}, d, J=8,6 \mathrm{~Hz}, \mathrm{H}-$ $\left.2^{\prime}, 6^{\prime}\right) .{ }^{13} \mathrm{C}-\mathrm{NMR}\left(125,8 \mathrm{MHz}, \mathrm{CD}_{3} \mathrm{OD}\right) \delta(\mathrm{ppm}): 94.5(\mathrm{C}-$ 8), 99.3 (C-6), 104.6 (C-10), 116.4 (C-3', C-5'), 123.8 (C1'), 130.8 (C-2', C-6'), 137.2 (C-3), 148.1 (C-2), 158.3 (C5), 160.6 (C-4'), 162.6 (C-9), 165.7 (C-7), 177.4 (C-4).
Compound 1 The positive results on the test using $\mathrm{FeCl}_{3}$ reagent (yellowish green) and Shinoda test $(\mathrm{Mg}+\mathrm{HC} 1)$ (yellow) of compound $\mathbf{1}$ indicated that it was a flavonoid compound [9]. The absorbtion maxima at 267 (band II) and $367 \mathrm{~nm}$ (band I) in the UV spectrum supported that $\mathbf{1}$ was a flavonol with a free 3-hydroxyl group. The batochromic shift of band I on adding $\mathrm{NaOH}$ reagent $(38 \mathrm{~nm})$ and $\mathrm{AlCl}_{3}$ $+\mathrm{HCl}$ reagent $(54 \mathrm{~nm})$ indicated the presence of a hydroxyl group at C-4' and C-5, respectively. The presence of a hydroxyl group at C-7 was exhibited by batochromic shift of band II $(9 \mathrm{~nm})$ on adding $\mathrm{NaOAc}$ reagent. No batochromic shift on adding $\mathrm{NaOAc}+\mathrm{H}_{3} \mathrm{BO}_{3}$ reagent supported that $\mathbf{1}$ didn't have ortho-di hydroxyl group at A and B rings. The IR spectrum of $\mathbf{1}$ clearly disclosed absorbtion bands for $\mathrm{OH}$ group $\left(3414 \mathrm{~cm}^{-1}\right)$, chelated carbonyl group $\left(1659 \mathrm{~cm}^{-1}\right)$, and aromatic $\mathrm{C}=\mathrm{C}\left(1613,1567,1510 \mathrm{~cm}^{-1}\right)$. The ${ }^{1} \mathrm{H}-\mathrm{NMR}$ spectrum of 2 exhibited four doublet proton signals at $\delta_{\mathrm{H}}$ $6.17,6.38,6.89$ and 8.07. Two doublet proton signals at $\delta_{\mathrm{H}}$ $6.17(J=1.9 \mathrm{~Hz})$ and $6.38(J=1.9 \mathrm{~Hz})$ due to a pair of meta coupled protons H-6 and H-8 in the A-ring, respectively, supported the presence of a hydroxyl group at C-5 and C-7. While two doublet proton signals at $\delta_{\mathrm{H}} 6.89(\mathrm{~J}=9.2 \mathrm{~Hz}, \mathrm{H}-$ $\left.3^{\prime}, 5^{\prime}\right)$ and $8.07\left(J=9.2, \mathrm{H}-2^{\prime}, 6^{\prime}\right)$ due to two pairs of orthocop;ed protons in the B-ring, confirmed the presence of a hydroxyl group at C-4'. The ${ }^{13} \mathrm{C}-\mathrm{NMR}$ spectrum exhibited 15 carbon signals which corresponded to $\mathbf{1}$, containing five oxy aryl carbons [ $\delta_{\mathrm{C}} 148.1(\mathrm{C}-2), 158.3(\mathrm{C}-5), 160.6\left(\mathrm{C}-4^{\prime}\right)$, $162.6(\mathrm{C}-9)$, and $165.7(\mathrm{C}-7)]$, one oxyolefine carbon $\left[\delta_{\mathrm{C}}\right.$ $137.2(\mathrm{C}-3)]$, and one carbonyl carbon [ $\left.\delta_{\mathrm{C}} 177.4(\mathrm{C}-4)\right]$. The correlation spectroscopy (HMQC and HMBC) spectral data supported complete assignment of all proton-bearing carbon signals of $\mathbf{1}$. Futher supporting evidence of structure $\mathbf{1}$ for kaemferol came from comparison of the ${ }^{1} \mathrm{H}-\mathrm{NMR}$ and ${ }^{13} \mathrm{C}$-NMR spectral data with those of reported data in literature $[10,11]$ From the above results, compound 1 was proposed for the structure of kaempferol ([3,5,7,4'tetrahydroxy flavone)

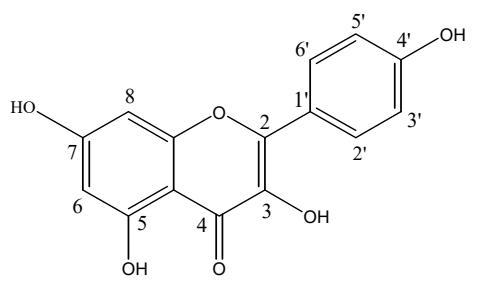

(1)

Based on the immunostimulat activity assay known that kaemferol had phagocytosis index (FI) of 1.846. The isolated flavonoid could be categorized as a strong immunostimulat because its FI was bigger than 1.5 [12]. The kaemferol is one of the flavonoid compound predicted had immunostimulant activity because it could improve the 
body imune system induced by cyclophosphamide so percentage of $\mathrm{T}$ CD8+ cel increase [13]. Flavonoid was predicted to increase the proliferation of $B$ cells and lymphocyte $\mathrm{T}$ cells, release of specific cytokines such as TNF- $\alpha$, IFN- $\gamma$ and IL-4. In addition, it was also able to stimulate phagocytic activity of macrophages, lysosomal enzyme activity, and release of nitric oxide by macrophages [14]. Thus the kaemferol had potency to be developed as immunostimulat agent.

\section{CONCLUSIONS}

It had been separated the fenolic compound, namely kaemferol from the acetone extract of $P$. calomelanos's aerial part. It was obtained as yellow needles crystal with m.p. of $271-273{ }^{\circ} \mathrm{C}$. It could be categorized as a strong immunostimulat because its FI was bigger than 1.5 namely 1.846. Thus the kaemferol had potency to be developed as immunostimulat agent.

\section{ACKNOWLEDGMENT}

We thanks the Directorate of Research and Innovation Empowerment, Directorate of Empowerment for Research and Development, the Ministry of Research, Technology and High Education, Indonesia, for financial support through the Superior Fundamental Research of Higher Education Grant 2018.

\section{REFERENCES}

[1] Steenish V \& Holttum RE. Flora Malesiana. London: Junk Publisher, 1982.

[2] Visoottiviseth, P., Francesconi, K., Sridokchan, W. "The potential of Thai indigenous plant spesies for the phytoremidianation of arsenic contaminated land", Eviron Pollut, 2002, Vol. 118, no. 3, pp: 453-611.

[3] Anonimous. Pityrogramma calomelanos (L) Link. (http://tropical.theferns.info/viewtropical.php?id=Pityrogramm a+calomelanos. Accessed 18 Oktober 2017).
[4] Wollenweber, E., Dietz, V.H., Schilling, G., Favre-Bonvin, J., Smith, D.M. "Flavonoids from the chemotypes of the goldback fern Pityrogramma triangularis", Phytochemistry, 1985, Vol. 24, No. 5, pp: 965-971.

[5] Sutoyo, S., Ismono, Mitarlis, Wardana, A.P. 2018. "Secondary metabolites isolated from the dichloromethane extract of silver fern (Pityrogramma calomelanos)". Research Journal of Pharmaceutical, Biological, and Chemical Sciences, 2018, Vol. 9, No. 1, pp: 566-570.

[6] Baratawidjaja $\mathrm{K} \&$ Rengganis I. Basic Immunology. $9^{\text {th }}$ ed. Jakarta: Indonesian University, 2010.

[7] Wagner H. Immunomodulatory Agents from Plants. Jerman: Birkhauser Verlag, 1999.

[8] Aldi, Y., Ogiana, N., Handayani, D. "Imunomodulator assay several subfraction of ethyl acetate extract of meniran (Phyllanthus niruri L) on male mice using carbon clearance method". Proceeding of National Seminar Recent Development of Pharmacy Sciences and Clinic III.. Faculty of Pharmacy, Andalas University, 4-5 October 2013. 134-148.

[9] Robinson, T, The Organic Constituents of Higher Plants. $6^{\text {th }}$ ed., North Amherst, MA : Cordus Press, 1991.

[10] Sutoyo, S., Indrayanto, G., Zaini, N.C. "Studies on chemical constituents of Chingia sakayensis (Zeiller) Holtt.” Natural Product Communications, 2007, Vol. 2, No. 5, pp: 579-580.

[11] Markham, K.R., Geiger, H. "1 $\mathrm{H}$ nuclear magnetic resonance spectroscopy of flavonoids and their glycosides in hexadeuterodimethylsulfoxide". In The Flavonoids. Advances in research since 1986. Harborne JB (Ed). London: Chapman \& Hall, 1994.

[12] Wagner, H., Immunomodulatory Agents from Plants. Jerman: Birkhauser Verlag, 1999.

[13] Mankaran, S., Dinesh, K., Deepak, S., \& Gurmeet, S. 2013. "Typhonium flagelliforme: A multipurpose plant". International Research Journal of Pharmacy. 2013, Vol 4, No. 3, pp: 45-48.

[14] Nworu, C.S., Akah, P.A., Okoye, F.B., Proksch, P., Esimone, C.O. "The effect of Phyllantus niruri aqueous extract on the activation of murine lymphocytes and bone-derived macrophages",. Immunol Invest, 2010, Vol. 39, No. 3, pp:246-67. 